\title{
CONA and UEA-I Ligands During Tooth Development Reveals Differences between Human and Rodents Models and Shows the Beginning of Mineral Extracelular Matrix Secretion
}

\author{
Ligandos CONA y UEA-I Revelan Diferencias entre Humanos y en Modelos Roedores Durante el \\ Desarrollo Dental y Muestran el Comienzo de la Secreción de la Matriz Mineral Extracelular
}

\author{
"Déborah Pitta Paraíso Iglesias; **Moacyr Jesus Barreto de Melo Rego; \\ ******Eduardo Isidoro Carneiro Beltrão \& *Ana Paula Veras Sobral
}

IGLESIAS, D. P. P.; REGO, M. J. B. M.; BELTRÃO, E. I. C. \& SOBRAL, A. P. V. CONA and UEA-I ligands during tooth development reveals differences between human and rodents models and shows the beginning of mineral extracelular matrix secretion. Int. J. Morphol., 30(3):1100-1105, 2012.

SUMMARY: Many of Glycobyological aspects of human development remain still unclear, mainly in oral science, and this could be observed in a lack of literature with few and old papers about this subject. During tooth histo-morphogenesis changes occur in basement membrane composition, expression of signaling molecules and in localization of cell surface components, where glyco components could be involved. In this sense, this work aimed to analyze the ConA ligands commonly founded in glycoproteins cores and UEA-I ligands since fucolization is a Key event in many physiological and pathological processes. Therefore 15 jaws of human fetuses were ethically obtained, histologicaly processed and then submitted to lectin histochemistry with appropriated controls. The results showed that lectins staining increase their intensity during dental development; ConA only starts to recognize glucose/mannose residues on ectomesechymal cells in the crow phase revealing its ligands when the enamel matrix starts to be secreted. Interestingly, Con A ligands were not founded in the basement membrane of the stratum intermedium of the enamel differing from rodents models. The staining pattern of UEA-I was different, starting to be positive in the ectomesenchyma since the bud stage and shown variable expression in cell type and staining intensity, which appeared be directly proportional to the progress of odontogenesis. Thus, this work shows that Con A and UEA-I exhibit a growing staining directly proporcional to ameloblasts and odontoblasts cytodiferenciation and revels some glycan differences between human odontogenesis and rodents models.

KEY WORDS: Odontogenesis; Carbohydrates; Lectin histochemistry.

\section{INTRODUCTION}

Tooth development involves morphogenesis, epithelial histogenesis and cell differentiation. The consecutive morphological stages of lamina, bud, cap and bell are also characterized by changes in epithelial histogenesis. Differential cell proliferation rates, apoptosis, and alterations in adhesion and cell shape lead to the positioning of groups of cells with different functions. Moreover, changes occur in basement membrane composition, expression of signalling molecules and localization of cell surface components (Lesot $\&$ Brook, 2009). Many transcription factors, growth factors and growth factor receptors have been found in dental development and are involved in epithelial-mesenchymal interaction (Hikake et al., 2003).
Given their ubiquitous presence and varied complexity on all cell surfaces, glycans have many diverse roles in development and various physiological systems of complex multicellular organisms (Varki et al., 2008). Only little information is available about glycobiology events of oral development in addiction to this there is a lack in literature with few and old papers about this subject. But this few information revels critical roles of carbohydrates in this processes, like the key role of glycosaminoglycans in organization, and structure of gums and teeth and the critical function of the sacharyde on glycoconjugates (Haltiwanger $\&$ Lowe, 2004). The good news is that many aspects of these glycans could be deciphered by lectins.

\footnotetext{
* Oral Pathology Laboratory, Dentistry College, Pernambuco University (UPE), Camaragibe, Brazil.

** Keizo Asami Immunopathology Laboratory (LIKA), Federal University of Pernambuco (UFPE), Recife, Brazil.

${ }^{* * *}$ Biochemistry Department, Biological Science Center, Federal University of Pernambuco (UFPE), Recife, Brazil.
} 
Lectins are structurally diverse carbohydrate-binding proteins or glycoproteins that agglutinate cells and recognize carbohydrates in oligosaccharides and glycoconjugates (Gemeiner et al., 2009). By virtue of their binding specifities, lectins have been used in histochemistry, providing a sensitive detection system for changes in glycosylation and carbohydrate expression that that may occur during embryogenesis, growth and disease (Campos et al., 2006). Tumour lectinology has so far shown cytochemical and histochemical differences between normal and transformed oral tissues including in a single class of tumour (Sobral et al., 2010).

Among many lectins we chose ConA that recognize glucose and mannose resídues and UEA-I that recognizes L-fucose, because their ligands are involved in many key cellular processes and are structural components of important molecules like glycoproteins and glycosaminoglycans. In this sense this work aimed to evaluate Con A and UEA-I ligands spatially and temporally during different phases of human odontogenis comparing with data of rodent models.

\section{MATERIAL AND METHOD}

Specimens. Jaws samples of human fetuses $(n=15)$ at 10 28 weeks of gestation were obtained from Professor Barros Lima and Professor Bandeira Filho Children Hospitals in Recife, State of Pernambuco, Brazil after approval of University of Pernambuco Ethical Committee. All specimens were fixed in $10 \%$ formalin and embedded in paraffin, and then $5 \mu \mathrm{m}$ of tissue sections were stained with haematoxylineosin for evaluation of morphological and developmental phases of odontogenesis.

Lectin Histochemistry. Four-micrometer-thick sections of the specimens were deparaffinized in xylene and hydrated in graded series of alcohol (100 - 70\%). Slices were treated with $0.1 \%(\mathrm{w} / \mathrm{v})$ trypsin solution for $2 \mathrm{~min}$ at $37^{\circ} \mathrm{C}$ and with a $0.3 \%(\mathrm{v} / \mathrm{v})$ methanol- $\mathrm{H}_{2} \mathrm{O}_{2}$ solution for $30 \mathrm{~min}$ at $25^{\circ} \mathrm{C}$ and then incubated with HRP-conjugated lectins (Con AHRP and UEA-I-HRP at 50mg/mL). PBS (10 mM phosphate buffer, $\mathrm{pH} 7.2,150 \mathrm{mM} \mathrm{NaCl}$ ) was used to prepare all solutions and as washing solution between each step. Peroxidase was visualized with a solution of diaminobenzidine- $\mathrm{H}_{2} \mathrm{O}_{2}$ for 5-8 min than counter-staining in Hematoxylin and evaluated by light microscopy. Lectinbinding inhibition assays were developed by incubating lectin with its corresponding specific sugars, methyl-a-Dmannoside for Con A and L-fucose for UEA-I (300mM) prior to sample incubation and replacing the lectin for PBS too. Cases of Mucoepidermoide carcinoma were used as positive controls and all experiments were done on triplicate.

\section{RESULTS}

The deciduous tooth germs were founded from the final button stag (in the $14^{\text {th }}$ week of fetus development) until the start of the crown formation (from the $24^{\text {th }}$ week of development), with the earlier development in the anterior portion of the jaw. The tooth buds in the early stages of crown formation exhibited the beginning of matrix secretion of the mantle dentin and enamel.

There were no evidences of glucose / mannose expression by Con A during cap and initial bell phases as indicated by the absence of lectin staining. But this patterns of staining changed substantially during $23^{\text {rd }}$ week of intrauterine development. Con A positivity started to be observed in dental papilla with staining intensity ranged from poor to moderate increasing as the cells became closer of the dental epithelium (Figs. 1A and 1B). This structure showed intensely stained on the papilla periphery too (Figs. 1A). In the tooth germ at the crown stage Con A was positive at the limit between pre- dentin and ameloblasts, in a weakly pattern and on dentin and enamel matrix (Figs. 1C and 1D), while the staining in the apical portion of the ameloblasts (Fig. 1E) and apical portion of odontoblasts cytoplasm was intense too (Fig. 1B).

Differing from ConA, UEA-I staining was observed since the button until crown phase. This lectin showed a variable expression in cell type and intensity of staining, which appeared be directly proportional to the progress of odontogenesis. The tooth buds (15 weeks of development), during the bell phase, showed weak positive staining on ectomesenchymal cells. Meanwhile in $16^{\text {th }}$ weeks of intrauterine development these same cells revealed strong staining on ectomesenchyme and its limit with epithelium, indeed, the epithelial cells of the enamel were moderately stained (Fig. 2C). In bell phase (18 weeks) were observed weak cytoplasmic staining on ectomesenchymal cells of the follicle, dental papilla (Fig. 2A), and extracellular matrix deposited at the boundary between the epithelium and dental papilla (Fig. 2B). With 23 weeks of intrauterine development the germ showed papilla and follicle ectomesenchymal cells moderately stained, differing from odontoblasts which exhibited intense staining pattern, mainly in areas corresponding to the vertices of future cusps. The epithelial cells near the inner and outer epithelium were positive, however, the central portion of the stellate reticulum showed no expression for the UEA-I ligands (Fig. 2E). On the $25^{\text {th }}$ weeks, at the crown stage dental germs present dental papilla, odontoblasts, ameloblatos matrix of enamel and dentin intensely stained. This finding was also observed in fetuses between 26 and 28 weeks age of gestational (data not shown). 


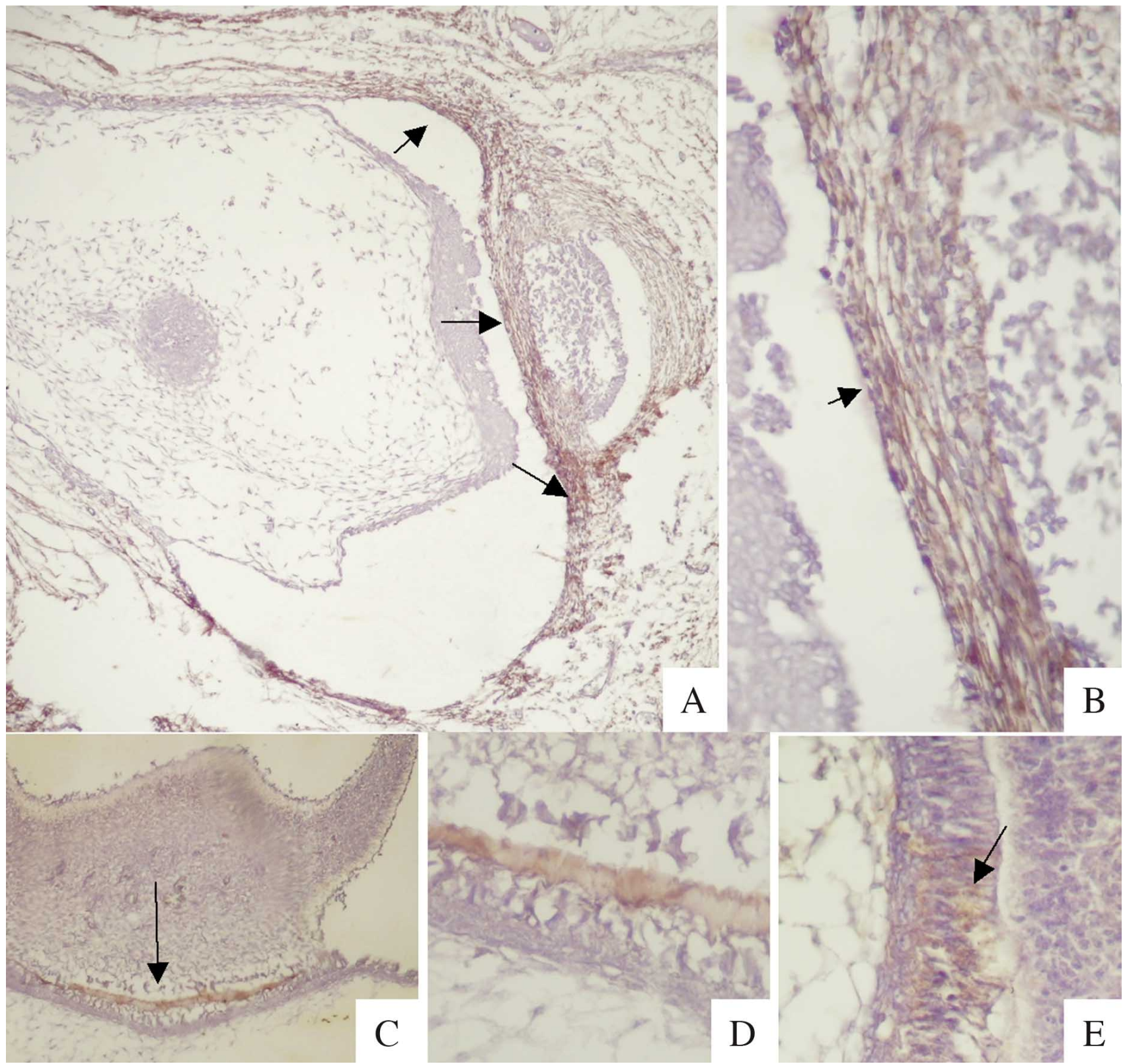

Fig. 1. A) ConA staining on inner epithelium of enamel organ (100x) and b) 400x. C) On the crow phase ConA ligands are expressed on enamel matrix (100x) and d) 400x. E) Ameloblast cytoplasma are recognized by the lectin (arrows).

\section{DISCUSSION}

The understanding of inductive phenomena has been increasingly demanded in the search for better understanding of cellular and molecular behavior pattern in dental normalcy, developmental disorders and reconstruction, so animal models like rodents, zebrafishand, first lower molar and even computacinal has been used to describe these mechanisms (Lesot \& Brook). Many molecular processes involved in odontogenesis are still poorly understood mainly glycobiologic ones. Gene knockout experiments in mice have demonstrated a critical role in embryogenesis for all major classes of glycans, as well as for certain classes of monosaccharides (Varki et al.). As might be expected, the resulting embryonic phenotypes are complex, and no single mechanism can easily explain the causes of lethality. The gol of this work was to evaluate spatial and temporal changes of UEA-I and ConA ligands during tooth human 


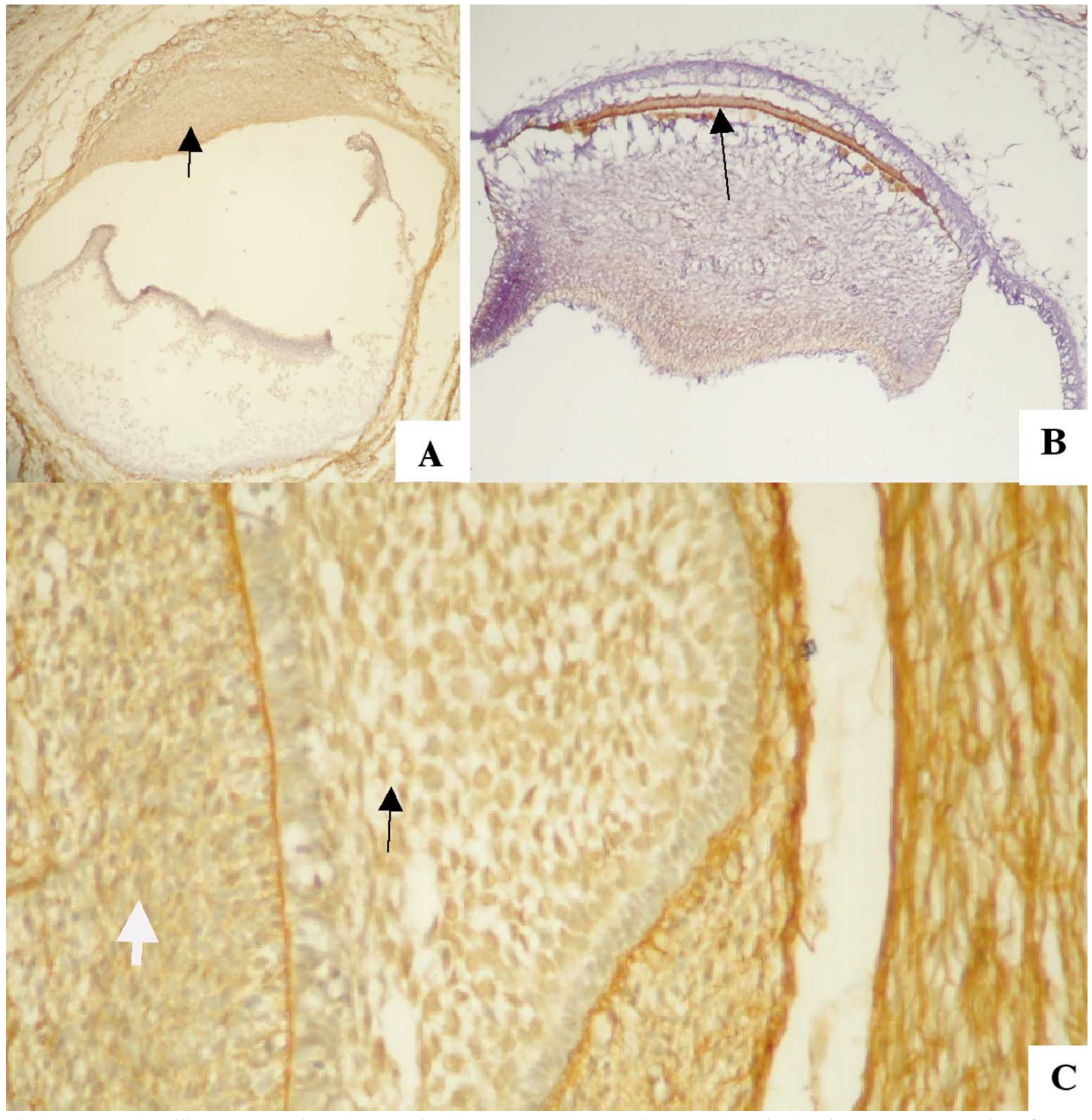

Fig. 2. A) Dental papilla (arrow) moderately recognized by UEA-I (100x). B) The enamel matrix showing a strong expression of UEAI ligands (100x). C) On bell phase, ectomesenchymal cells (write arrow) were stained as its limit with epithelium, indeed, the epithelial cells of the enamel were moderately stained (black arrow)(400x).

development to validate animal models more representative of human molecular profiles.

According Campos et al. (2006) the processes of cell differentiation and dedifferentiation include changes in the composition of oligosaccharides and their distribution on cell surfaces. On odontogenesis the changes of carbohydrates expression may act as modulators of the dental germs formation process, they can change pivotal functions like ligation pattern of growth factors, as well as the movements of migration and recognition that are involved in tooth formation (Fuenzalida et al., 2000). Some authors have highlighted the role of cell surface proteoglycans (sindecan-1) and matrix glycoproteins 
(tenascin) as active participants of inductive mechanisms (Hikake et al.; Arana-Chavez \& Massa, 2004).

The expression of Con A ligands are shown in the cells of the enamel and dental papilla of the teeth that were in bell and crown phases. Indeed the interface Ameloblast / extracellular matrix / odontoblasts exhibited intense staining partter and this results corroborates the findings of some studies with rats models (Nakai et al.,1985; Blottner \& Lindner, 1987; Kobayashi et al., 1989). However, Kobayashi et al. and Nakamura \& Ozawa (1990) observed in rats dental germs positivity for Con A ligands in the basement membrane of the enamel stratum intermedium, this findings were very different for ours that shown total absence of ConA ligands in this region suggesting that metabolic differences between species could be responsible for such discordant results.

Other divergent results about animal models of dental development has been observed on literature for example: zebrafish does not require the expression of bmp4 and bmp2 differing from the mammalian orthologs that are required virtually in all stages from initiation to hard tissue formation, these molecules playing an important roles in tooth development (Kondo, 2007). These models differences are founded in other events and organs like isoflavonas metabolism in mammalian cells (Bursztyka et al., 2008).

We founded that in the crown stage Con A ligands pattern was positive at the boundary between pre- dentin and ameloblasts staining weakly dentin matrix and enamel, while the staining in the apical portion of the ameloblasts was intense, as in the apical cytoplasm of odontoblasts. These results suggest that expression and/or availability of ConA ligands is closely related to the degree of differentiation shown by these cells. The expression occurs when the preodontoblasts and pre-ameloblasts differentiate into cells secreting dentin matrix enamel, respectively (Nakai et al.; Kobayashi et al.).

Ameloblasts and odontoblasts in fetuses from $23^{\text {th }}$ week, showed intense Con A staining, especially in structures that correspond to the vertices of future cusps. According to (Arana-Chavez \& Massa) the progression of cell cytodifferentiation occurs in the regions of future cusps or incisal border toward the cervical region and this process of mineralization appears to be dependent on the presence of glucose which justifies the high staining for this lectin.

The temporal expression in all phases of dentinogenesis and different spatial expression mainly observed in the membrane glycogonjugates founded of UEAI ligands are in agreement with literature results (Nakai et al.; Nakamura \& Ozawa; Lemus et al., 1997; Dan et al., 1997; Jowett et al., 1992). Our results suggest that L-fucose expression in dentinogenesis is similar between human and rodents models and we hipotyze that this monosaccharide was intensily required on dentinogenesis. For example, disruption of protein O-fucosylation causes a defect in Notch receptors that results in a severe embryonic phenotype (Stanley, 2007).

Ectomesenchymal Condensation behind the tooth germ has show positivite with temporal increment staining for booth lectins but there is a spatial diference. While UEA is positive since button phase ConA only recognize its ligands from the crown stage, when formed papilla and dental follicle were alredy. This lectins can be used in dental germs for determining the onset secretion of mineral matrix, since the expression of glucose and fucose only will be positive when differentiation of precursor cells in secretory odontoblasts and ameloblasts occurs. According to this (Nakamura \& Ozawa) suggest that ameloblastic differentiation occurs during the modification of the expression of glycolipids and glycoproteins of the middle stratum

Untill now for our knowledge our study is the first on to realize experiments in glycobiological aspects during human odontogenesis with human fetuses tissues showing some diferences between experimental models and confirming the necessity of new researches for animal models more reliable of the glycomolecular events or improvement of existing ones.

ACKNOWLEDGMENTS. This work was financially supported by CNPq, FACEPE and CAPES.

IGLESIAS, D. P. P.; REGO, M. J. B. M.; BELTRÃO, E. I. C. \& SOBRAL, A. P. V. Ligandos CONA y UEA-I revelan diferencias entre humanos y en modelos roedores durante el desarrollo dental y muestran el comienzo de la secreción de la matriz mineral extracelular. Int. J. Morphol., 30(3):1100-1105, 2012.

RESUMEN: Los aspectos glicobiológicos del desarrollo humano siguen siendo poco investigados, sobre todo en odontología, y esto puede ser observado en la literatura por los escasos y antiguos artículos sobre el tema. Durante la histomorfogénesis del diente se producen cambios en la composición de la membrana basal, en la expresión de moléculas de señalización y en la localización de la superficie celular de los componentes, donde los glico componentes podrían estar involucrados. Este trabajo tuvo como objetivo analizar los ligandos de la ConA ya que glucosa/manosa son comúnmente encontrados en núcleos de glicoproteínas y ligandos de la UEA-I debido a fucolización es un evento clave en muchos procesos fisiológicos y patológicos. Fueron obtenidas 15 
mandíbulas de fetos humanos, procesadas y tratadas mediante histoquímica de lectinas con controles apropiados. Los resultados mostraron que la intensidad de tinción de las lectinas aumenta durante el desarrollo del diente. ConA sólo comienza a reconocer residuos de glucosa/manosa en células ectomesénquimales en la fase de corona revelando cuando la matriz de esmalte empieza a ser secretada. Curiosamente, ligandos de la ConA no se encontraron en la membrana basal de la capa intermedia del esmalte, difiriendo de los modelos de roedores. El patrón de tinción de la UEA-I fue diferente, empieza a ser positivo en el ectomesenquima desde la etapa de brotación y muestra variable expresión en el tipo de célula y la intensidad de la tinción, que parecía ser directamente proporcional al progreso de la odontogénesis. Por lo tanto, este trabajo demuestra que la Con A y la UEA-I presentan una coloración que crece directamente proporcional a citodiferenciación de los ameloblastos y odontoblastos, y revela algunas diferencias entre el estándar glicano de odontogénesis humanos y los modelos roedores.

PALABRAS CLAVE: Odontogénesis; Hidratos del carbono; Histoquímica con lectinas.

\section{REFERENCES}

Arana-Chavez, V. E. \& Massa, L. F. Odontoblasts: the cells forming and maintaining dentine. Int. J. Biochem. Cell Biol., 36(8):1367-73, 2004.

Blottner, D. \& Lindner, E. Light-microscopic studies on spatial and temporal binding of the lectins concanavalin A, wheatgerm agglutinin and peanut agglutinin in early rat odontogenesis. Arch. Oral Biol., 32(1):35-42, 1987.

Bursztyka, J.; Perdu, E.; Tulliez, J.; Debrawer, L.; Delous, G.; Canlet, C.; De Sousa, G.; Rahmani, R.; Benfenati, E. \& Cravedi, J. P. Comparison of genistein metabolism in rats and humans using liver microsomes and hepatocytes. Food Chem. Toxicol., 46(3):939-48, 2008.

Campos, L. M.; Cavalcanti, C. L.; Lima-Filho, J. L.; Carvalho, L. B. \& Beltrão, E. I. Acridinium ester conjugated to lectin as chemiluminescent histochemistry marker. Biomarkers, 11(5):480-4, 2006.

Dan, M. Lectin binding patterns of odontogenic epithelium in the rat during various phases of molar tooth development. J. Osaka Dent. Univ., 31(2):39-46, 1997.

Fuenzalida, M.; Lemus, S.; Illanes, J.; Montiel, E.; Acuña, O. \& Lemus, D. Histochemical detection of sugar residues in lizard teeth (Liolaemus gravenhorsti): a lectin-biding study. Biol. Res., 33(3-4):215-26, 2000.

Gemeiner, P.; Mislovicová, D.; Tkác, J.; Svitel, J.; Pätoprstł, V.; Hrabárová, E.; Kogan, G. \& Kozár, T. Lectinomics. II: A highway to biomedical/clinicaldiagnostics. Biotechnol. Adv., 27(1):1-15, 2009.
Haltiwanger, R. S. \& Lowe, J. B. Role of Glycosylation in Development. Annu. Rev. Biochem., 73:491-537, 2004.

Hikake, T.; Mori, T.; Iseki, K.; Hagino, S.; Zhang, Y.; Takagi, H.; Yokoya, S. \& Wanaka, A. Comparasion of expression patterns between CREB family transcription factor OASIS and proteoglycan core protein genes during murine tooth development. Anat. Embryol. (Berl), 206(5):373-80, 2003.

Jowett, A. K.; Kimber, S. J. \& Fergurson, M. W. Immunofluorescent lectin binding patterns and glycoprotein co-localization in the developing murine molar tooth. Arch. Oral Biol., 37(4):30314, 1992.

Kobayashi, Y.; Akita, H.; Kagayama, M. \& Kindaichi, K. Lectinbinding sites in the growing end of rat incisors. Shika Kiso Igakkai Zasshi, 31(1):1-12, 1989.

Kondo, M. Bone morphogenetic proteins in the early development of zebrafish. FEBS J., 274(12):2960-7, 2007.

Lemus, D.; Lemus, R.; Romero, S.; Arancibia, N. \& Fuenzalida, M. Detection of sugar residues in rabbit embryo teeth with lectin-horseradish peroxidase conjugate: II. A light microscopal study. J. Morphol., 231(2):175-84, 1997.

Lesot, H. \& Brook, A. H. Epithelial histogenesis during tooth development. Arch. Oral Biol., 54(1):S25-33, 2009.

Nakai, M.; Tatemoto, Y.; Mori, H. \& Mori, M. Lectin-binding patterns in the developing tooth. Histochemistry, 83(5):45563, 1985.

Nakamura, H. \& Ozawa, H. Lectin cytochemistry on the stratum intermedium and the papillary layer in the rat incisor enamel organ. Arch. Histol. Cytol., 53(4):352-69, 1990.

Sobral, A. P.; Rego, M. J.; Cavalacanti, C. L.; Carvalho, L. B. Jr. \& Beltrão, E. I. ConA and UEA-I lectin histochemistry of parotid gland mucoepidermoid carcinoma. J. Oral Sci., 52(1):49-54, 2010 .

Stanley, P. Regulation of Notch signaling by glycosylation. Curr. Opin. Struct. Biol., 7(17):530-5, 2007.

Varki, A.; Freeze, H. H. \& Vacquier, V. D. Glycans in development and Systemic Physiology. In: Essentials of Glycobiology. $2^{\text {nd }}$ ed. New York, Cold Spring Harbor, 2008.

\section{Correspondence to:}

Dr. Ana Paula Veras Sobral

Rua Monte Alverne, 107/05

Hipódromo - Recife - PE

52041-610

BRAZIL

Email: anapvsobral@yahoo.com.br

Received: 10-04-2012 Accepted: 19-07-2012 